\title{
Gyrate atrophy with hyperornithinaemia: different types of responsiveness to vitamin $\mathrm{B}_{6}$
}

\author{
S. HAYASAKA,${ }^{1}$ T. SAITO,${ }^{2}$ H. NAKAJIMA,${ }^{1}$ Y. TAKAKU,${ }^{1}$ T. SHIONO,${ }^{1}$ \\ K. MIZUNO ${ }^{1} \mathrm{~K}$. OHMURA, ${ }^{2}$ AND K. TADA ${ }^{2}$
}

From the Departments of ${ }^{1}$ Ophthalmology and ${ }^{2}$ Paediatrics, Tohoku University School of Medicine, Sendai, Japan

SUMMARY Three cases of Japanese patients with gyrate atrophy of the choroid and retina with hyperornithinaemia were studied clinically and biochemically. The types of disease differed in responsiveness to vitamin $\mathbf{B}_{6}$. In-vivo responsiveness to vitamin $\mathbf{B}_{6}$ was correlated with in-vitro data. It is suggested that the in-vitro examination of the influence of pyridoxal phosphate on ornithine ketoacid transaminase activity in cultured fibroblasts may be useful in ascertaining the efficacy of vitamin $B_{6}$ treatment in gyrate atrophy. In addition the early development of the fundus lesions was observed in one case (case 1), and the ciliary body abnormality and chorioretinal atrophy were noted in another (case 3 ).

Large doses of vitamin $B_{6}$ have been tried in the treatment of gyrate atrophy of choroid and retina since Simell and Takki ${ }^{1}$ found hyperornithinaemia in these cases and several investigators ${ }^{2-5}$ confirmed deficient activity of ornithine ketoacid aminotransferase in cultured fibroblasts or lymphocytes from the affected patients. Genetic heterogeneity of the disease in responsiveness to vitamin $B_{6}$ was suggested recently. ${ }^{367}$ But a study of both in-vivo and in-vitro responsiveness to vitamin $\mathbf{B}_{6}$ has been lacking. We therefore investigated whether in-vivo responsiveness to vitamin $B_{6}$ is correlated with in-vitro data.

\section{Case reports}

Three patients with gyrate atrophy with hyperornithinaemia, their parents and a sister, and normal controls were examined in this study.

Case 1. A 5-year-old boy was first seen at the Departments of Paediatrics and Ophthalmology of Tohoku University Hospital at the age of 2 years, because his mother noticed he had thick speech and brown hair. Delivery and development were normal. The boy was the second son of a consanguineous marriage. On examination he appeared normal, except for hyperornithinaemia $(8 \cdot 48 \mathrm{mg} / \mathrm{dl}(84 \cdot 8 \mathrm{mg} / \mathrm{l})$ serum, Table 1) and hyperornithinuria. Thick speech and brown hair were not observed. Ophthalmological Correspondence to S. Hayasaka, MD, Department of Ophthalmology, Tohoku University School of Medicine, Sendai, Miyagi 980. Japan. examination showed no abnormal lesion in the ocular fundi at the ages of 2 and 3 years. Yellow-white spots at the peripheral fundus (Fig. 1) and an abnormal reflex in the macular area were first noted at the age of 4 years. The visual acuity of both eyes was $0 \cdot 3$ with correction of myopia ( $-2 \mathrm{D})$. The optical media were clear. He complained of night blindness at the age of 5 years. The electroretinogram was subnormal. The ciliary processes were normal by cycloscopy. The clinical diagnosis of early gyrate atrophy was made.

Case 2. An 8-year-old boy first noted decreased

Table 1 Amino acid concentration in serum ( $\mathrm{mg} / \mathrm{dl}$ )

\begin{tabular}{|c|c|c|c|c|c|}
\hline & \multirow[t]{2}{*}{ Case 1} & \multirow[t]{2}{*}{ Case 2} & \multirow[t]{2}{*}{ Case 3} & \multicolumn{2}{|c|}{ Normal } \\
\hline & & & & Mean & Range (2 SD) \\
\hline Ornithine & 8.48 & 12.95 & 6.92 & 0.96 & $0.36-1.56$ \\
\hline Lysine & 1.06 & 1.49 & $2 \cdot 15$ & $2 \cdot 23$ & $1.49-2.97$ \\
\hline Histidine & $1 \cdot 61$ & $1 \cdot 74$ & $1 \cdot 73$ & $1 \cdot 38$ & $1 \cdot 04-1 \cdot 72$ \\
\hline Arginine & 1.03 & $2 \cdot 06$ & $1 \cdot 26$ & $1 \cdot 25$ & $0 \cdot 49-1 \cdot 72$ \\
\hline Threonine & 0.96 & 1.48 & $2 \cdot 20$ & $1 \cdot 30$ & $0 \cdot 78-1 \cdot 82$ \\
\hline Serine & 1.94 & $1 \cdot 76$ & $2 \cdot 48$ & 1.66 & $1 \cdot 14-2 \cdot 18$ \\
\hline Glu. + glutamin & $6 \cdot 51$ & $8 \cdot 25$ & $9 \cdot 22$ & & \\
\hline Glycine & $1 \cdot 71$ & $2 \cdot 01$ & $2 \cdot 67$ & $2 \cdot 03$ & $1 \cdot 23-2 \cdot 83$ \\
\hline Alanine & $3 \cdot 16$ & $3 \cdot 27$ & $2 \cdot 93$ & $3 \cdot 28$ & $1 \cdot 70-4 \cdot 86$ \\
\hline Valine & $2 \cdot 27$ & $2 \cdot 71$ & $3 \cdot 19$ & $2 \cdot 62$ & $1 \cdot 50-3 \cdot 74$ \\
\hline Cystine & $0 \cdot 88$ & $1 \cdot 26$ & $0 \cdot 49$ & & \\
\hline Methionine & $0 \cdot 54$ & $0 \cdot 41$ & $0 \cdot 44$ & $0 \cdot 34$ & $0 \cdot 20-0 \cdot 48$ \\
\hline Isoleucine & $0 \cdot 88$ & $0 \cdot 83$ & $0 \cdot 98$ & $0 \cdot 86$ & $0 \cdot 32-1 \cdot 44$ \\
\hline Leucine & $1 \cdot 76$ & $1 \cdot 78$ & $2 \cdot 22$ & 1.64 & $0 \cdot 66-2 \cdot 60$ \\
\hline Tyrosine & $1 \cdot 12$ & $1 \cdot 38$ & $1 \cdot 10$ & $1 \cdot 16$ & $0 \cdot 62-1 \cdot 70$ \\
\hline Phenylalanine & $1 \cdot 12$ & 1.04 & $1 \cdot 38$ & 1.27 & $0 \cdot 69-1 \cdot 85$ \\
\hline Proline & $1 \cdot 30$ & 0.95 & $2 \cdot 87$ & 1.66 & $0 \cdot 82-2 \cdot 50$ \\
\hline Citrulline & & & $0 \cdot 30$ & $0 \cdot 37$ & $0.09-0.65$ \\
\hline
\end{tabular}

SI conversion: $\mathrm{g} / \mathrm{l}=\mathrm{mg} / \mathrm{ml} \times \mathrm{l}$. 


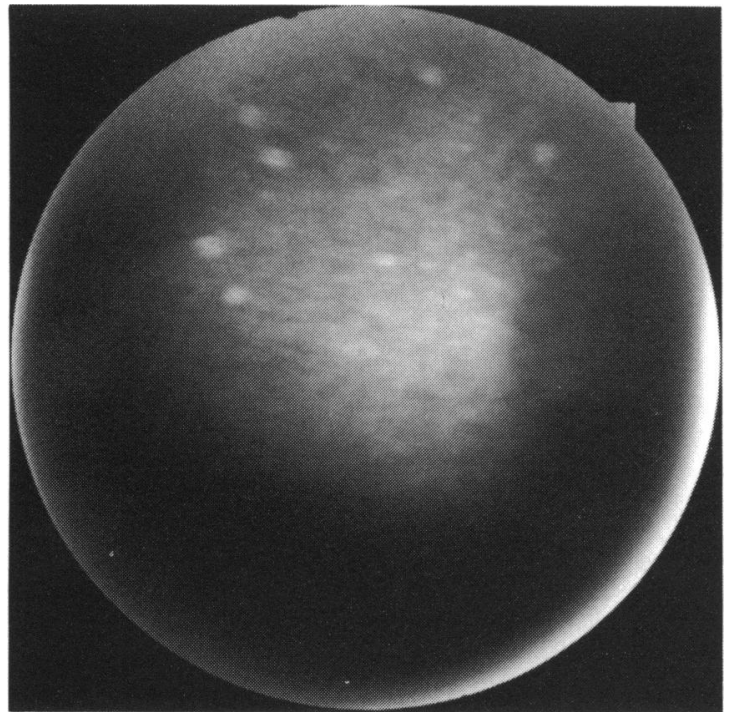

Fig. 1 Fundus photograph of case 1. Yellow-white spots at the peripheral fundus at the age of 4 years.

vision at the age of 5 years, and glasses were prescribed for myopia. At the age of 8 he was referred to the retina service of our department suffering from night blindness. Ophthalmological examination showed best corrected visual acuity was RE $0 \cdot 4$ with correction of myopia ( $-8 \mathrm{D})$, LE $0 \cdot 4$ with correction of myopia $(-10 \mathrm{D})$. The lens in each eye was clear. Typical chorioretinal atrophy with scallop margins at the peripheral fundus and an abnormal reflex in the macular area were ophthalmoscopically noted (Fig. 2 ). The Goldmann visual fields showed a concentric constriction. The dark adaptation curve was monophasic. The electroretinogram was subnormal, and the electro-oculogram was flat. The ciliary processes were normal by cycloscopy.

There was no history of any other family members with ocular disease. Consanguinity was denied. No physical or mental abnormalities were found. Hyperornithinaemia $(12.95 \mathrm{mg} / \mathrm{dl}(129.5 \mathrm{mg} / \mathrm{l}))$ was noted (Table 1). The clinical diagnosis of typical gyrate atrophy was made.

Case 3. An 18-year-old man was first seen at the Department of Ophthalmology at Kagoshima University at the age of 17 because his vision had deteriorated with age. The clinical diagnosis of gyrate atrophy was made there, and he was referred to our department.

The parents were first cousins. There was no family history of night blindness. Two weeks after birth he had suffered from erysipelas. At that time heterotaxis was noted. Ophthalmological examination at the age of 17 showed best corrected visual acuity was RE 0.03 with correction of myopia ( $-13 \mathrm{D})$, LE 0.6 with correction of myopia $(-14 \mathrm{D})$. A posterior subcapsular cataract was observed in both eyes, more severe in the right eye.

Ophthalmoscopically chorioretinal atrophy with the characteristic scalloped border approached the posterior pole (Fig. 3). Cycloscopically short and scanty ciliary processes were noted (Fig. 4). The

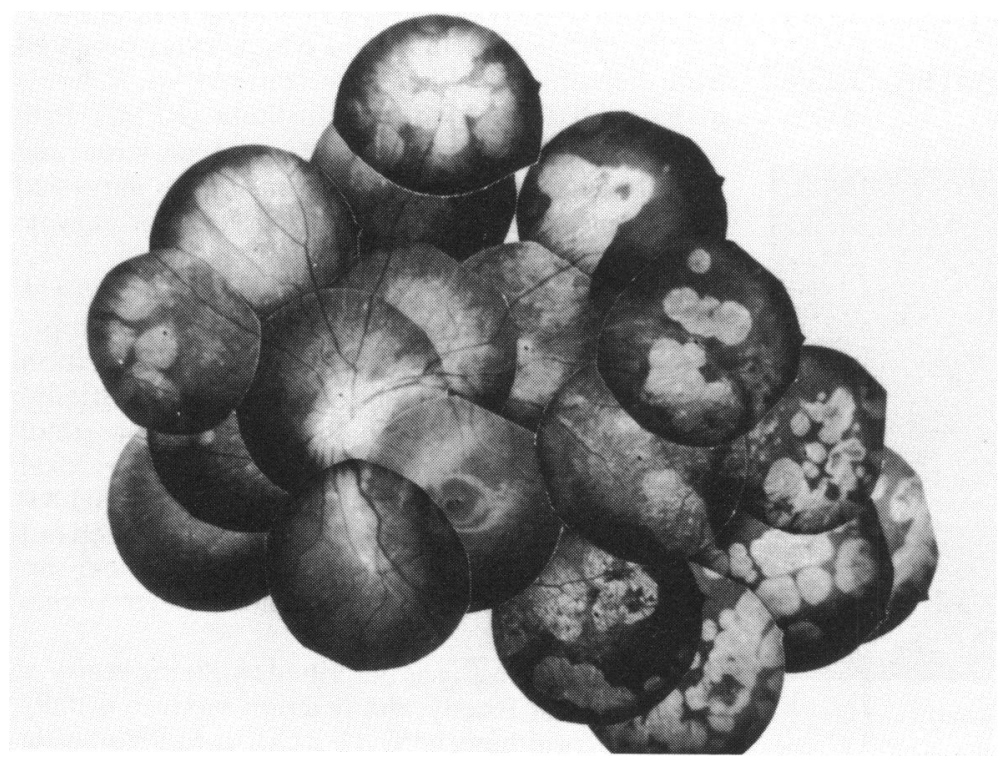

Fig. 2 Fundus photograph of case 2. Irregular and sharply defined atrophy at the periphery. 
Fig. 3 Fundus photograph of case 3. Chorioretinal border approached to the posterior pole. atrophy with scalloped

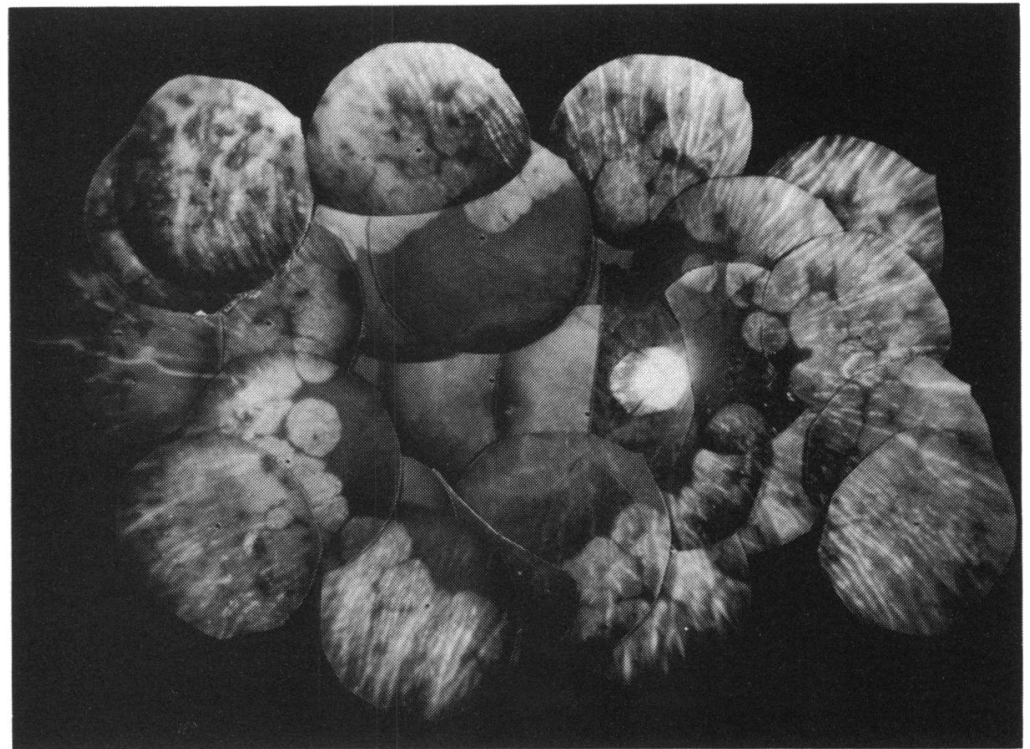

Goldmann visual fields showed a concentric constriction. The electroretinogram was subnormal. No physical or mental abnormalities were found. Hyperornithinaemia $(6.92 \mathrm{mg} / \mathrm{dl}(69.2 \mathrm{mg} / \mathrm{l}))$ was noted (Table 1). The clinical diagnosis of typical gyrate atrophy was made.

Parents and a sister. The parents and a sister of these patients had good visual acuity and no abnormal atrophic lesions in the ocular fundi. Serum amino acids were within normal limits.

\section{Materials and methods}

Serum amino acids were measured on a Hitachi amino acid analyser (type 835).

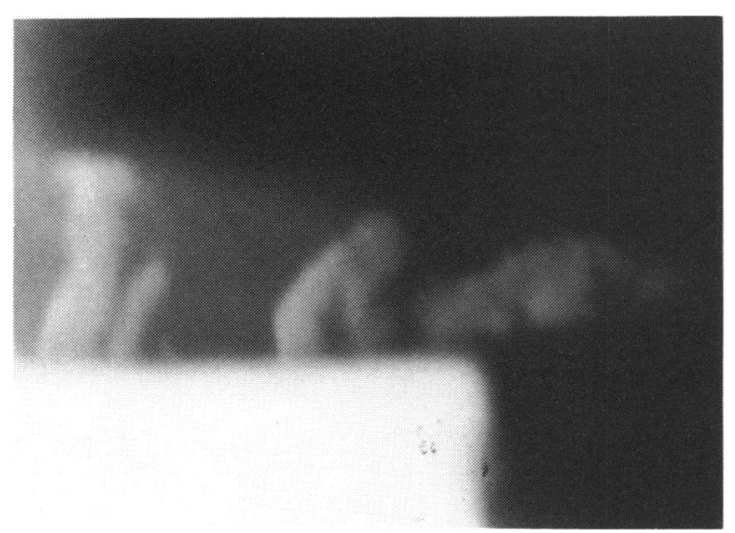

Fig. 4 Cyclogram of case 3. Short and scanty ciliary processes.
Skin biopsy material was cut into small fragments and cultured in Eagle's medium (MEM) supplemented with $10 \%$ fetal calf serum and nonessential amino acids. When the monolayers had grown to confluency, they were trypsinised and the fibroblasts were harvested for enzyme analysis. Cell lysates were prepared by twice freezing and thawing and further sonication at 60 kilocycles for $10 \mathrm{~s}$ of the washed cells in saline. For one enzyme assay a cell lysate obtained from 1 to $2 \times 10^{6}$ cells was required.

Cell extracts of phytohaemagglutinin-transformed lymphocytes were prepared by the method of Berger. ${ }^{8}$ Briefly, the peripheral blood lymphocytes prepared from heparinised blood were cultured for 72 hours in Roswell Park Memorial Institute (RPMI) 1640 medium supplemented with $10 \%$ fetal calf serum and phytohaemagglutinin $(5 \mu \mathrm{g}$ per $\mathrm{ml})$. Cells harvested were sonicated at 60 kilocycles for $10 \mathrm{~s}$ for enzyme assay.

Ornithine ketoacid aminotransferase activity was determined by spectrophotometric and radioisotopic methods. Spectrophotometric assay is a modification of the method of Katsunuma and coworkers. ' Briefly, the reaction mixture usually contained $4 \mu$ mol ornithine, $1 \mu \mathrm{mol} \alpha$-ketoglutarate, $40 \mathrm{nmol}$ pyridoxal phosphate, and enzyme source (cell lysate) at pH 8.0 in a total volume of $0.4 \mathrm{ml}$. Incubation was carried out at $37^{\circ} \mathrm{C}$ for $30 \mathrm{~min}$. The amount of pyrroline-5-carboxylate formed was determined spectrophotometrically.

Radioisotopic assay as described by Phang et al. ${ }^{10} 11$ was employed. Briefly, the reaction mixture usually contained ornithine-1-14 $\mathrm{C}(1 \mu \mathrm{Ci}), \alpha$-ketoglutarate 


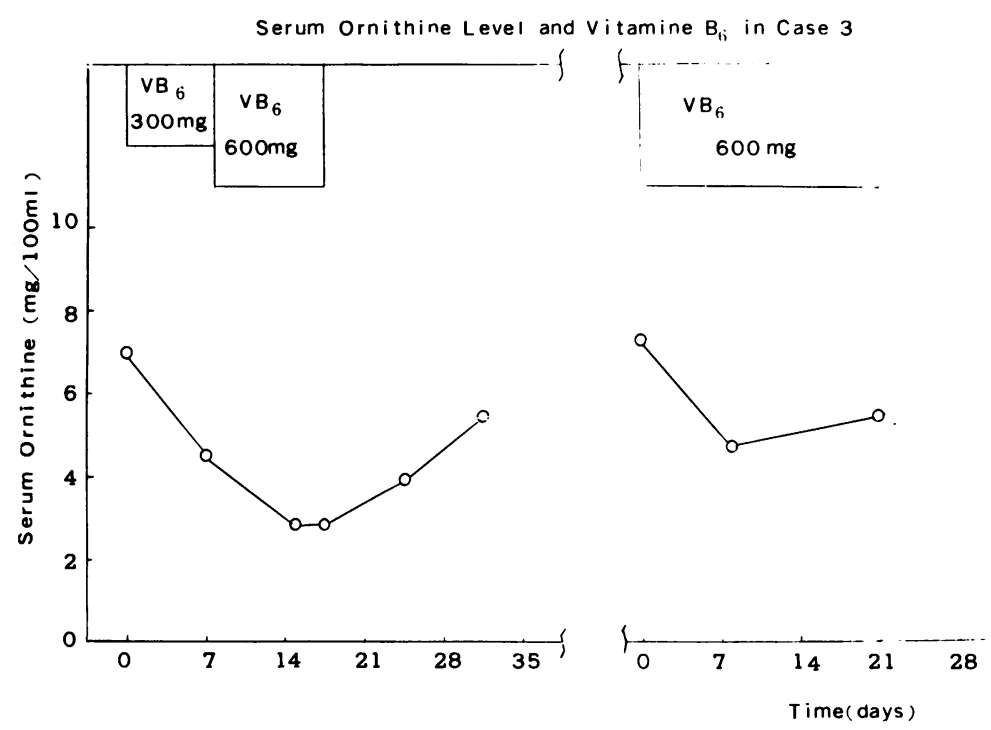

Fig. 5 Serum ornithine level after vitamin $B_{6}$ administration in case 3.

$(0 \cdot 7 \mathrm{mM})$, pyridoxal phosphate $(4 \mu \mathrm{g} / \mathrm{ml}), 0 \cdot 1 \mathrm{M}$ phosphate buffer $(\mathrm{pH} 8 \cdot 0)$, and cell lysate $(100 \mu \mathrm{l})$ in a final volume of $0.25 \mathrm{ml}$. Incubation was carried out at $37^{\circ} \mathrm{C}$ for $1 \mathrm{~h}$. The reaction was terminated with addition of $50 \mu \mathrm{l}$ of $6 \mathrm{~N} \mathrm{HC1}$. The radioactivity of ${ }^{14} \mathrm{C}-\Delta$ pyrroline-5-carboxylate formed was determined after separation from ${ }^{14} \mathrm{C}$-ornithine by an ion-exchange column.

Protein content was determined by the method of Lowry et al. ${ }^{12}$

All values are expressed as mean of 3 different experiments.

Table 2 Ornithine ketoacid aminotransferase activity in vitro in PHA-transformed lymphocytes and cultured skin fibroblasts

\begin{tabular}{|c|c|c|}
\hline & \multicolumn{2}{|c|}{ Specific enzyme activity } \\
\hline & $\begin{array}{l}\text { PHA-transformed } \\
\text { lymphocytes* }\end{array}$ & $\begin{array}{l}\text { Cultured skin } \\
\text { fibroblastst }\end{array}$ \\
\hline $\begin{array}{l}\text { Family } 1 \\
\text { Patient (case 1) } \\
\text { Father } \\
\text { Mother }\end{array}$ & $\begin{array}{l}0.045 \\
1 \cdot 075 \\
1 \cdot 538\end{array}$ & Not detectable \\
\hline $\begin{array}{l}\text { Family } 2 \\
\text { Patient (case 2) } \\
\text { Father } \\
\text { Mother } \\
\text { Sister }\end{array}$ & $\begin{array}{l}0.011 \\
0.535 \\
0.945 \\
1.028\end{array}$ & Not detectable \\
\hline $\begin{array}{l}\text { Family } 3 \\
\quad \text { Patient (case 3) } \\
\text { Father }\end{array}$ & Not detectable & $\begin{array}{l}\text { Not detectable } \\
72\end{array}$ \\
\hline $\begin{array}{l}\text { Normal controls } \\
\qquad \text { Mean } \pm S D(n=5)\end{array}$ & $2 \cdot 02 \pm 0 \cdot 29$ & $148 \pm 26$ \\
\hline
\end{tabular}

\section{Results}

As shown in Table 1 , these 3 patients showed a marked increase in serum ornithine and almost normal values of the other amino acids.

IN-VIVO RESPONSE TO VITAMIN B 6

After 2 weeks of high dosage of vitamin $B_{6}(300 \mathrm{mg}$ per day) the serum ornithine level and ERG did not change in cases 1 and 2 . The serum ornithine level following vitamin $B_{6}(300-600 \mathrm{mg}$ per day) in case 3 is shown in Fig. 5. The serum ornithine level in case 3 decreased with a maximum of $60 \%$ reduction, responding to concentration of vitamin $B_{6}$. After stopping the administration of vitamin $B_{6}$ the ornithine level returned to the initial level. High-dose vitamin $B_{6}$ treatment showed no significant improvement in the electroretinogram, visual acuity, or visual field in case 3 .

\section{IN-VITRO RESPONSE TO PYRIDOXAL PHOSPHATE (VITAMIN B 6 -AL-PHOSPHATE)}

Ornithine ketoacid aminotransferase activity in the phytohaemagglutinin-transformed lymphocytes and cultured skin fibroblasts is shown in Table 2 . When assayed at $10^{-4} \mathrm{M}$ pyridoxal phosphate, little or no enzyme activity was detected in all 3 affected patients. The activities in carrier parents and sister showed approximately $50 \%$ of the mean control values, indicating heterozygotes. Fibroblasts from case 3 showed an increase in enzyme activity when concentrations of pyridoxal phosphate were increased in the assay medium (Fig. 6). In the presence of $2 \times 10^{-3} \mathrm{M}$ pyridoxal phosphate, ornithine ketoacid aminotransferase activity in the fibroblasts in this patient 
increased up to $25 \%$ of normal levels. Fibroblasts from cases 1 and 2 did not respond to pyridoxal phosphate in the ornithine ketoacid aminotransferase activity.

\section{Discussion}

The present study points to several conclusions. Firstly, there are types of gyrate atrophy with hyperornithinaemia which differ in their responsiveness to vitamin $B_{6}$, as shown by the responsive case 3 and the nonresponsive cases 1 and 2 . Secondly, in-vivo responsiveness to vitamin $B_{6}$ (Fig. 5) is correlated with in-vitro data (Fig. 6).

It seems probable that the vitamin $B_{6}$ responsive type (case 3) has the enzyme of high $\mathrm{Km}$ (Michaelis constant) value for pyridoxal phosphate. Our previous data ${ }^{13}$ show that the $\mathrm{Km}$ value for pyridoxal phosphate of the enzyme in the bovine ciliary body and iris is $1.0 \times 10^{-5} \mathrm{M}$. Fibroblasts from the vitamin $B_{6}$ responsive type (case 3 ) required a high concentration (over $1 \times 10^{-3} \mathrm{M}$ ) of pyridoxal phosphate for invitro enzyme activity. The data suggest the presence of enzyme with high $\mathrm{Km}$ for pyridoxal phosphate in the vitamin $B_{6}$ responsive type and enzyme deficiency in the vitamin $B_{6}$ nonresponsive type of the disease.

Although heterogeneity of gyrate atrophy in vitamin $B_{6}$ response has been previously reported, ${ }^{367}$ the relationship between in-vitro and in-vivo responsiveness has not been noted. Shih and coworkers ${ }^{3}$ reported only the in-vitro data of the effect of pyridoxal phosphate, while Kaiser-Kupfer and coworkers ${ }^{7}$ showed only the in-vivo reduction of plasma ornithine level in response to oral vitamin $B_{6}$. The value of the enzyme activity was not described in the preliminary report of Welber et al. ${ }^{6}$ The present study confirms the correlation of in-vivo and in-vitro responsiveness of gyrate atrophy to vitamin $B_{6}$ and the presence of different types. It also strongly suggests that the in-vitro examination of the influence of pyridoxal phosphate on enzyme activity in the cultured fibroblasts may help us to determine the efficacy of vitamin $B_{6}$ treatment in gyrate atrophy.

Case 1 had a normal appearance of the ocular fundi at the ages of 2 and 3 years. The yellowish white atrophic patches began at the age of 4 years. This is in agreement with the observation ${ }^{14} 15$ that ocular lesions begin at around the age of 4 years.

Cyloscopic observation is also interesting. We previously ${ }^{16}$ reported the high enzyme activity of ornithine ketoacid transaminase in the bovine retinal pigment epithelium, ciliary body, and iris. A cyclogram of case 3 (Fig. 4) shows the short and scanty ciliary processes. Cycloscopically, the ciliary processes in the affected children (cases 1 and 2) were normal, while those in the young adult patient (case

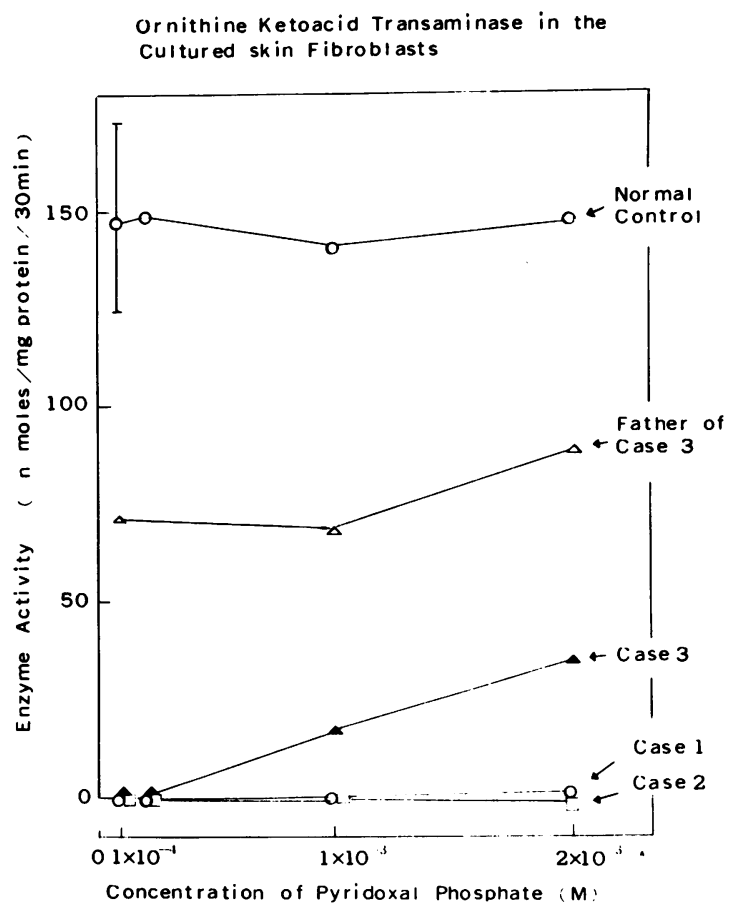

Fig. 6 Ornithine ketoacid aminotransferase in vitro in the cultured skin fibroblasts and pyridoxal phosphate concentration.

3) were short and scanty. Another young adult (21 years old) with gyrate atrophy showed similar lesions of the ciliary body (unpublished observation). The data suggested involvement of the ciliary body with age as well as retinochoroidal atrophy in the gyrate atrophy.

The authors thank Professor Ohba, Kagoshima University, for referring the patients. This study was supported in part by grants from the Ministry of Education and from the Ministry of Health and Welfare, Japan.

\section{References}

1 Simell O, Takki K. Raised plasma-ornithine and gyrate atrophy of the choroid and retina. Lancet 1973; i: 1031-3.

2 Senger RCA, Trijbels JMF, Brussaard JH, Deutman AF. Gyrate atrophy of the choroid and retina and ornithine-ketoacid aminotransferase deficiency. Pediatr Res 1976; 10: 894.

3 Shih VE, Berson EL, Mandell R, Schmidt SY. Ornithine ketoacid transaminase deficiency gyrate atrophy of the choroid and retina. Am J Hum Genet 1978; 30: 174-9.

4 Kaiser-Kupfer MI, Valle D, Del Valle LA. A specific enzyme defect in gyrate atrophy. Am J Ophthalmol 1978; 85: 200-4.

5 O'Donnell JJ, Sandman RP, Martin SR. Gyrate atrophy of the retina. Inborn error of L-ornithine: 2 -oxoacid aminotransferase. Science 1978; 200: 200-1.

6 Weleber RG, Kennaway NG, Buist NR. Vitamin $B_{6}$ in management of gyrate atrophy of choroid and retina. Lancet 1978; ii: 1213. 
7 Kaiser-Kupfer MI, Valle D, Bron AJ. Clinical and biochemical heterogeneity in gyrate atrophy. Am J Ophthalmol 1980; 89: 219-22.

8 Berger SL. Lymphocytes as resting cells. In: Jakoby WB, Pastan IH, eds. Methods in Enzymology. New York: Academic Press. 1979; 58: 486-94.

9 Katsunuma N, Matsuda Y, Tomino I. Studies on ornithineketoacid transaminase. I. Purification and properties. J Biochem 1964; 56: 499-503.

10 Phang JM, Downing SJ, Valle D. A radioisotopic assay for ornithine-transaminase. Anal Biochem 1973; 55: 272-7.

11 Valle D, Blaese RM, Phang JM. Increased sensitivity of lymphocyte pyrroline-5-carboxylate reductase to inhibition by proline with transformation. Nature 1975; 253: 214.

12 Lowry OH, Rosebrough NJ, Farr AL, Randall RJ. Protein measurement with folin phenol reagent. J Biol Chem 1951; 193: 265-75.

13 Shiono T, Hayasaka S, Mizuno K. Partial purification and certain properties of ornithine ketoacid aminotransferase in bovine ciliary body and iris. Exp Eye Res in press.

14 Yatziv S, Statter M, Merin S. Metabolic studies in two families with hyperornithinemia and gyrate atrophy of choroid and retina. J Lab Clin Med 1979; 93: 749-57.

15 Rinaldi E, Stoppoloni GP, Savastano S, Russo S, Cotticelli L. Gyrate atrophy of choroid associated with hyperornithinemia: report of the first case in Italy. J Pediatr Ophthalmol 1979; 16: 133-5.

16 Hayasaka S, Shiono T, Takaku Y, Mizuno K. Ornithine ketoacid aminotransferase in the bovine eye. Invest Ophthalmol Visual Sci 1980; 19: $1457-60$. 